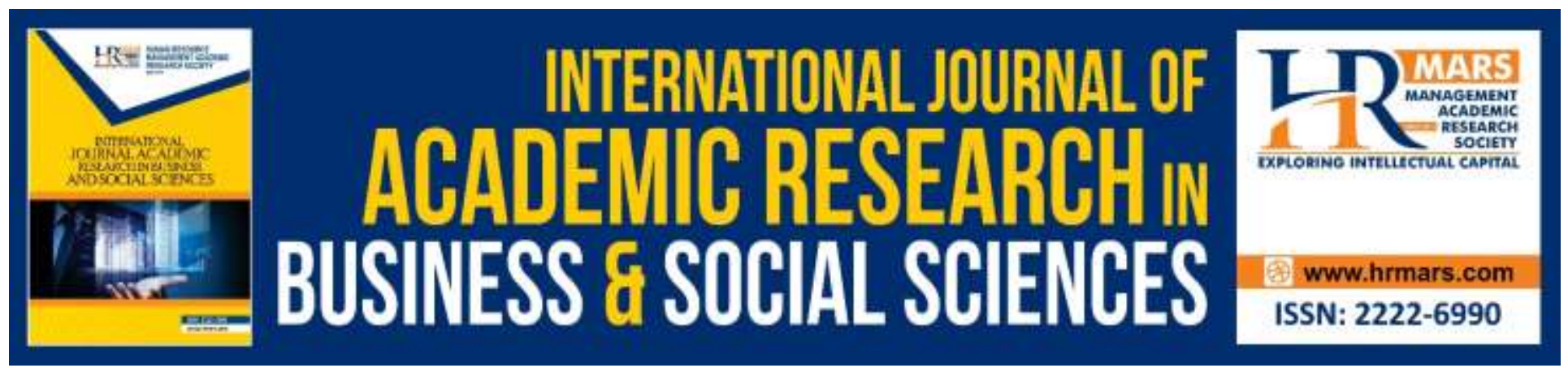

\title{
Economic and Non-Economic Paradox of Quality of Life of Bangladeshi Migrant Workers: A Qualitative Study
}

Md Wahidul Haque, Norizan Abdul Ghani

To Link this Article: http://dx.doi.org/10.6007/IJARBSS/v10-i4/7138

DOI:10.6007/IJARBSS/v10-i4/7138

Received: 09 February 2020, Revised: 17 March 2020, Accepted: 25 March 2020

Published Online: 10 April 2020

In-Text Citation: (Haque \& Ghani, 2020)

To Cite this Article: Haque, M. W., \& Ghani, N. A. (2020). Economic and Non-Economic Paradox of Quality of Life of Bangladeshi Migrant Workers: A Qualitative Study. International Journal of Academic Research in Business and Social Sciences, 10(4), 348-358.

Copyright: (C) 2020 The Author(s)

Published by Human Resource Management Academic Research Society (www.hrmars.com)

This article is published under the Creative Commons Attribution (CC BY 4.0) license. Anyone may reproduce, distribute, translate and create derivative works of this article (for both commercial and non-commercial purposes), subject to full attribution to the original publication and authors. The full terms of this license may be seen at: $\underline{\text { http://creativecommons.org/licences/by/4.0/legalcode }}$

Vol. 10, No. 4, 2020, Pg. 348 - 358

http://hrmars.com/index.php/pages/detail/IJARBSS

JOURNAL HOMEPAGE

Full Terms \& Conditions of access and use can be found at http://hrmars.com/index.php/pages/detail/publication-ethics 


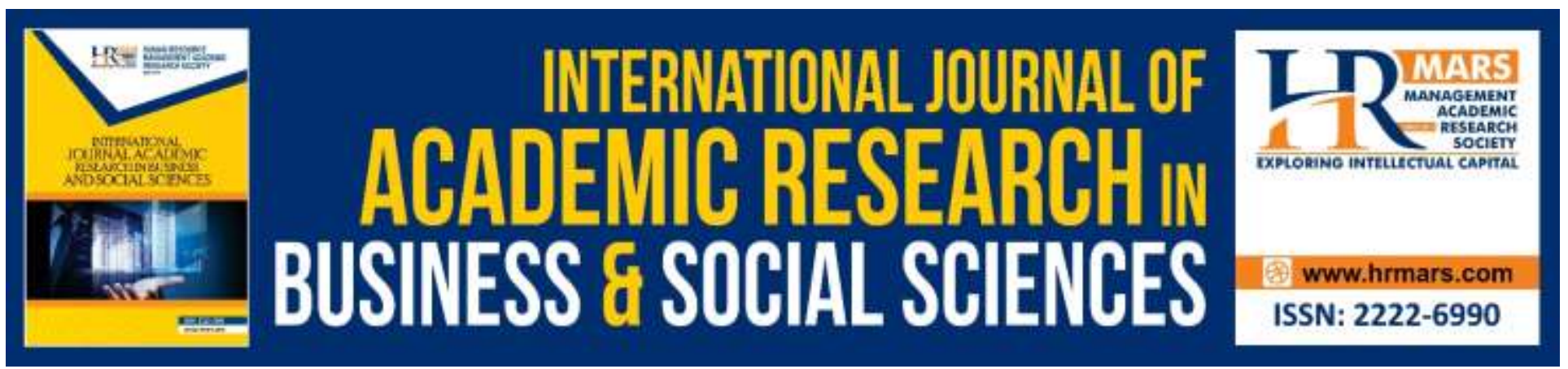

\title{
Economic and Non-Economic Paradox of Quality of Life of Bangladeshi Migrant Workers: A Qualitative Study
}

\author{
Md Wahidul Haque, Norizan Abdul Ghani \\ Faculty of Applied Social Sciences, University Sultan Zainal Abidin (UniSZA), Terengganu, Malaysia
}

\begin{abstract}
Migration studies are increasingly validating that non-economic factors like, subjective wellbeing or Quality of Life (QoL) carries substantial weight over the economic dimensions. Yet, there is a lack of research on economic and non-economic wellbeing or QoL of the migrant workers in Asia. This qualitative research investigated to find out the economic and non-economic factors effecting QoL of Bangladeshi construction workers in Malaysia. Thematic analysis was used to find out the effect of income, housing, and freedom on QoL. The scope of the study covers only the Bangladesh construction workers who have been in Malaysia for less than ten years. Outcome of this research suggest that paradox of economic activities pushing Bangladeshi construction workers towards noneconomic paradox like ignoring housing and legal freedom and pulling down the QoL.
\end{abstract}

\section{Introduction}

Lately, migration studies have increasingly validated that non-economic factors like, subjective wellbeing or QoL carries substantial weight over the economic dimensions (Amit, 2010; Amit \& Riss, 2014). Yet, subjective wellbeing or QoL of immigrants is known little ( Amit \& Riss, 2014). While conducting QoL research, advanced countries separately focus on migrant workers. A recent study finds out that Portuguese migrant workers are satisfied with job-related QoL in Switzerland (Neto et al., 2019). There is a lack of research on non-economic and economic QoL of the migrant workers in Asia (Reza et al., 2019), which also implies on Bangladesh and Malaysia. For the variations of the findings in previous researches many gaps are found in this area of migrant labour (Reza et al., 2019). These gaps demonstrate that experts in this field are yet to grasp the holistic picture of the economic and non-economic phenomenon of the migrant workers, let alone the workers, who are making all the decisions regarding their destination and economic activities.

Recent literature on migration emphasizes more on developing social networks, local language acquisition, sense of identity, and subjective wellbeing, which are basically of non-economic 
INTERNATIONAL JOURNAL OF ACADEMIC RESEARCH IN BUSINESS AND SOCIAL SCIENCES Vol. 10, No. 4, April, 2020, E-ISSN: 2222-6990 @ 2020 HRMARS

dimensions (Amit, 2012; Amit, 2010). Bangladeshi migrant workers are still putting more emphasis on the economic issue, which is rather putting them in trouble and lowering the QoL. Researchers found that there is a positive correlation between subjective QoL and material conditions (Havasi, 2013). Subjective QoL consists of subsistence, good health state, human relations, security of the individual, freedom, and the opportunity to develop (Havasi, 2013). This research aims to investigate the effect of economic issues like income and non-economic issues like housing and freedom on subjective QoL of migrant Bangladeshi construction workers in Malaysia. The study is limited to the workers staying for the last ten years in Malaysia.

\section{Literature Review}

Migration economists agree that 'economic integration' takes place when immigrants receive the same salary as natives (Borjas, 1990; Amit \& Riss, 2014). This integration of immigrants is usually a long-term process, which depends on the number of years of migration (YoM) in the destination country (Preston \& Grimes, 2019). YoM is an important consideration because there are time-specific effects of migration (Nowok, Van-Ham, Findlay \& Gayle, 2013) like knowing the people, their culture, or language of the host country. The latest migration researches reveal that subjective considerations (non-economic) form a very important factor that affects the immigrant integration process.

Unlike other sectors, economic integration is found to be low in the construction sector of Malaysia. Malaysians are at the top of the wage hierarchy while Bangladeshis are at the bottom (Reza et al., 2019). This difference is due to the presence of outsourcing companies in between the employers and Bangladeshi workers, though as per the minimum wage policy of 2016, both local and foreign workers are supposed to get at least RM 1,100 per month (Hwa et al., 2019). Nielsen (2014) has mentioned that the Indonesian migrant labors tolerate personal economic hardship, many works without salary in the initial periods to cover the fees charged by their recruitment agent (Nielsen, \& Sendjaya, 2014). These studies reflect the same picture of Bangladeshi workers. The scenario is rather worse because workers don't know why and how much money is deducted from their salary. This economic vulnerability unpleasantly impacts on economic QoL.

Quite a few studies documented the impact of living and working conditions on the physical and mental health of migrants, which ultimately affects the QoL. Migrant workers usually live and work in poor conditions like crowded and substandard places, eat food without any health consideration, sleep insufficiently, and often lack access to healthcare services (Alswaidi, Memish, Al Hakeem \& Atlam, 2013). On the contrary, their remittances mostly used for living expenses and to finance major household projects such as renovating or building a house back home and agricultural issues (Reza et al., 2019).

Some of the recent literature have shown how the lack of social security, freedom and low wage negatively impacts on their social wellbeing among the Indonesian labors in Malaysia (Nielsen \& Sendjaya, 2014; Smyth, Nielsen, Zhai, Liu, Liu, Tang, 2011). These cases are also found to be true in the case of Bangladeshi workers. Productivity and earnings are likely to be affected due to the lack of freedom of choice in the work environment (Ruhs, 2016). There is a huge difference in the migrant worker's sense of personal security and civic freedoms (Czaika, \& DeHaas, 2012). The migrant workers 
had lack of job security, poor salary but long working hours, low access to the public services, poor living and working conditions, lack of legal rights, and physical and mental stress towards their economic and social wellbeing or QoL (Reza et al., 2019).

\section{Theoretical Framework}

Noble laureate Amartya Sen conceptualized 'capability theory,' which proposes that subjective QoL or wellbeing of an individual worker could be assessed according to his/ her capabilities to work through individual freedom. One should not be evaluated according to the achievements but within the contexts of the real opportunities and freedim available to him/ her (Binder, 2014). Sen pragmatically defined the purpose of economic development as 'expanding the capability' and, therefore, the 'freedom of individuals' to fulfill their potential to lead a meaningful life (Binder, 2014). Figure 1 shows the relation of individual economic development through expanding their capability and freedom to fullfil the potential and their ultimate effect on QoL. Human beings must have equal possibilities and equal opportunities to function and real freedom of being and doing (Sen 2010). With equal opportunities, people have the freedom to demonestrate their capabilities, potentially reach their functioning and lead a high QoL. The same concern of freedom is raised for Bangladeshi migrant construction workers, though they have the capability for functioning and flourishing. Withholding the legal documents by the outsourcing agents and employers and binding or virtually captivating them to an unfavorable work situation raises the question of workers' freedom and QoL.

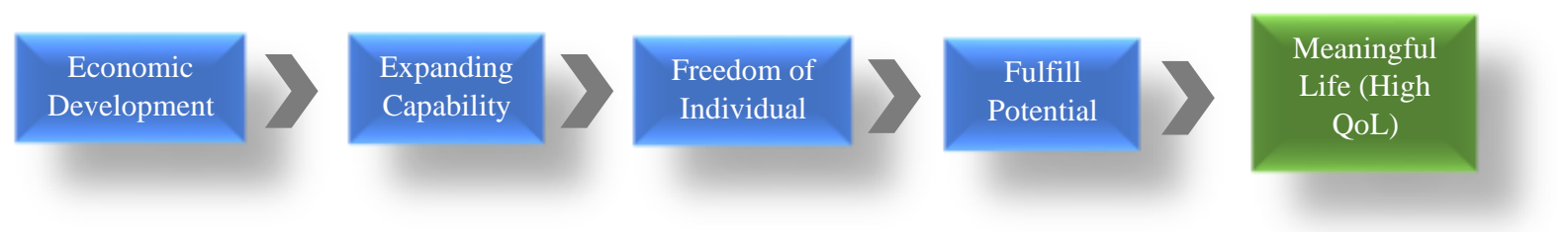

Figure 1: Factro effecting High QoL

Source: Researcher's understanding of Capability Theory

\section{Research Design and Methodology}

A qualitative research through thematic analysis was applied in this research to find out the economic and non-economic factors effecting QoL of Bangladeshi migrant workers in Malaysia. Atlas. ti version seven was used to find out the code, subtheme and themes of effect of income, housing, and freedom over QoL. The sample of the field study included Bangladesh migrant construction workers of Kuala Lumpur, Johor Bahru, Penang, and Kuala Terengganu, which were randomly selected from amongst the 11 districts of the mainland of Malaysian peninsular. Multilevel participants (Yin, 2015) were selected from the construction workers, outsourcing agents/ employers, Bangladeshi embassy personalities in Malaysia, and intellectuals in this field. Following the data saturation technique (Yin, 2015) interview of 22 were taken for thematic analysis.

\section{Results and Discussion Income Paradox}


INTERNATIONAL JOURNAL OF ACADEMIC RESEARCH IN BUSINESS AND SOCIAL SCIENCES Vol. 10, No. 4, April, 2020, E-ISSN: 2222-6990 @ 2020 HRMARS

Though, Bangladeshi migrant construction workers in Malaysia get a huge jump in income, but it is subjected to high fluctuation. Income depends upon the availability of job (construction work again depends upon the economic condition of Malaysia), networks with other workers in a different construction site, working experience, language proficiency, smartness to manage a job, legal documentation, CIDB card, and YoM (R-7). Chart: 1 shows the factors of income.

Monthly payment of 1,100 RM is the lowest wage (Hwa al., 2019) of Malaysia, but the questions remain, how many days in a month they can work? Many a time, it is half, in the initial days of migration so, one might earn only $600 \mathrm{RM}$ in a month (R-21). For not being able to fulfill all the factors of income, 1-4 YoM worker's income is very low. Life is further down if they are working in an outsourcing company because

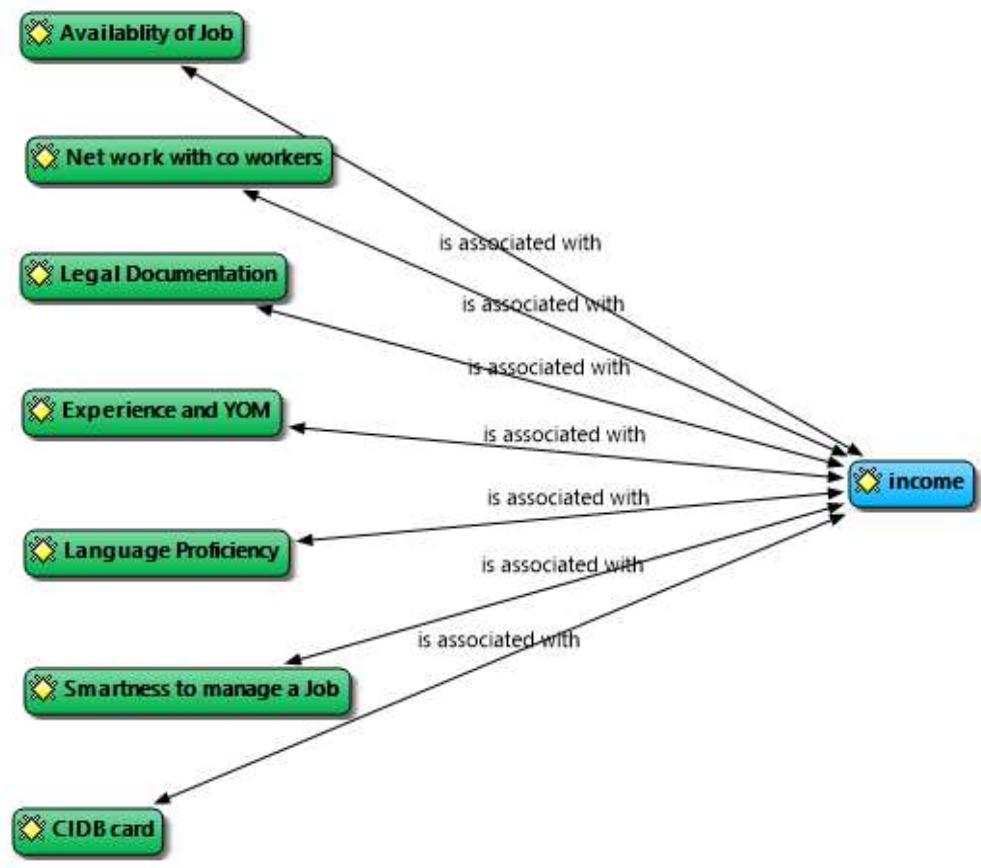

Chart 1: Factors of income they have to pay agents' commission ( $R-8)$ again. Many workers become undocumented during this period without being able to withstand the stress and hardship of earning and managing the expenditure (R-9).

After working for the whole month without holidays (except half-day on Friday/ Sunday), if the income is around RM 1,100 along with the overtime pay, then that's considered to be a low income. It is because Bangladeshi workers migrate to Malaysia with a lot of debts from microcredit and bank loans. Construction workers need to spend at least around RM 300-400 for own expense (R-8), need to keep aside around RM 400 for the yearly levies and RM 500 for clearing the loans (R-14) in initial four yeas (if he has borrowed to manage migration cost) family expenditure in Bangladesh of at least RM 300 remains as a big burden to the married workers. All together it becomes RM 1500-1600, which push many of them leave the initial working place in search of higher income (R-6). At least RM 1500 is considered as manageable income, which can take them through the hard way of life. Imam, (psudo name) respondent number seven reported that:

If I can earn at least 1500 Ringgit then I can pay back 500 Ringgit for bank loan, can keep aside 400 ringgits for levies, that makes 900 Ringgit and then the sum of RM 300 to 400 for my own expense here in Malaysia, which makes 1200 or 1300 and then rest to 300 for my family. It is a balanced way of income and expenditure, but if the income falls below 1500 Ringgit, then I can't bear the financial load (R-7). 
Workers with five to seven YoM earns a bit more because of experience and language proficiency (R6). They achieve a little bit of stability by this time. They can send money for the family to lead a better life, like renovating the house, contribute to the marriage of offspring, and education of the kids (R-14). Workers with the experience of eight to ten years have a higher quality of life. With the increased earning, they can purchase land or construct new houses or can save, someone can even invest (R-6).

Economic paradox of income is seen in following four occations of expolitations and vulnaribilities: Firstly, even after entitled to have huge earning, if someone has to shift from one workplace to another, there is no income for initial 15 days. Secondly, two/ three month's salary is withheld by the employer/ outsourcing agent. Thirdly, in some cases, they remain unemployed for months altogether. Fourthly, outsourcing company employs them even switching the occupations in completely new carrier track (R-21). This instabilities continue for the initial three to four years and then takes another three years to be stable and settle down. So, after six to seven years, they come to a balanced position, and then next three to four years, they can save and buy some property, like build a house or purchase some lands.

\section{Legal Documentation and Freedom Paradox}

In need of quick monitory gain and unabling to withstand the economic stress many of the workers move away from the outsourcing agents. While doing so, they leave behind the passport and become undocumented. If someone is undocumented, he can save RM 400 every month for the levies and also doesn't have to depend on the agent for his work and share his hard-earned money as a commission (R-11). There is a dilemma here, those who are smart, can learn the language early and can manage the financial transaction (with locals), might earn much more than other workers (bonded by the outsourcing agents) and lead a happy life. If one leaves the outsourcing agent and and can manage everything well, he earns even 2000-2500 RM in a month (R-15). In this case, the agent is not getting any commission (around 300-600 RM) for managing the job and not receiving any money for levies (400 RM). Many workers are encouraged to go for this type of illegal movement to save this RM 700 to 1,000 (R-21).

Because of the legal bindings of Malaysian labour law, workers under an outsourcing company can't work in any other construction site without a valid agreement, locally known as 'Surat' (R-11). This 'Surat' is again a precious document, which is only issued to a very wellknown and trustworthy worker (R-18). For that reason, even after having a valid passport and work permit, workers are legally liable to be arrested for working in a construction site not owned by his company. In this case of arrest and detention, the company management come and rescue him from police with a huge legal penalty. This penalty is adjusted afterwords from the workers' salary which is an act of extortion (R-18). That is why remaining documented is not appealing to many construction workers. This real freedom through documentation don't allow them an equal opportunity for individual economic development. 
Undocumented workers, on the other hand, are earning much more (around 700-1,000 RM ${ }^{1}$ ) from those who are bounded to the outsourcing agents. But the problem is they are undocumented, so they are afraid of the police, and they keep themselves hidden and lack real freedom. There are instances of more extortion to them because, if they are exploited or not given the money as per the oral contact (usually written contract is not signed before employing these undocumented workers), the workers cannot do anything, and cannot go to the police to complain (R-11).

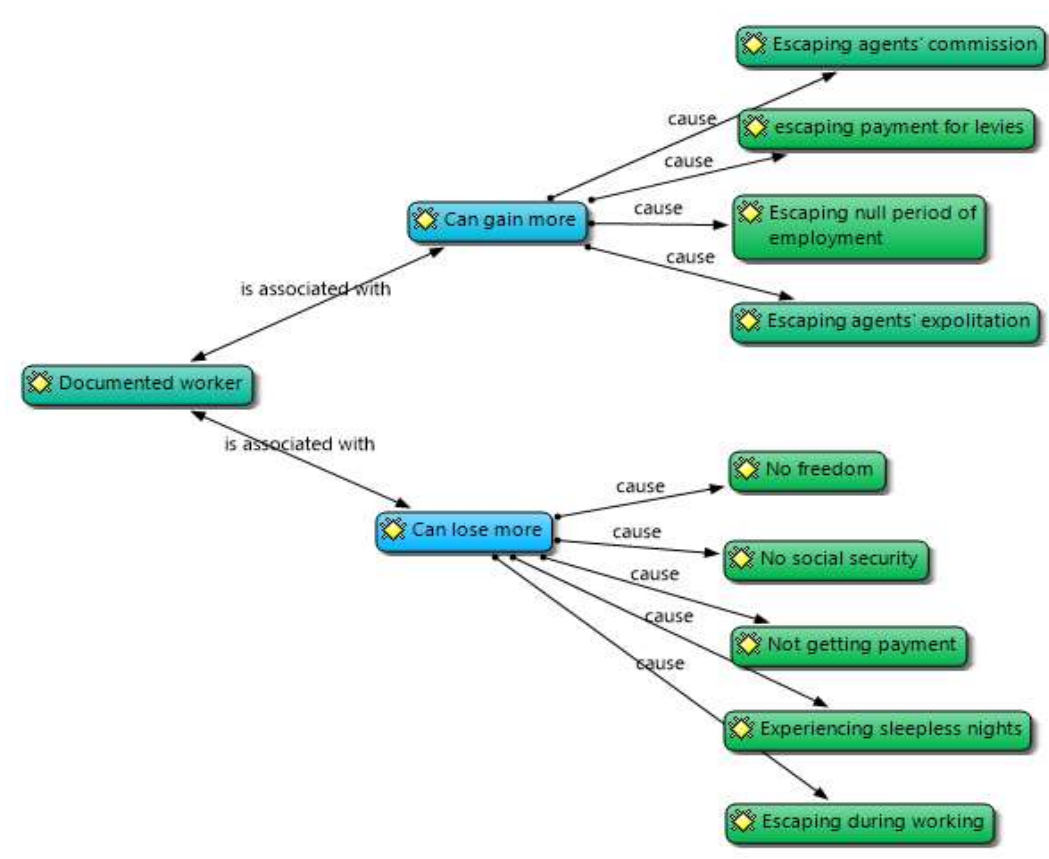

Chart 2: Loss and Benefit of an undocumented worker

Source: Output of atlas. ti from primary data collected

This scenario shows two sides of these undocumented workers; one is a bright part with more income, and the other is a dark side with no freedom and exploitation. An undocumented worker can earn more by escaping payment for levies (RM 400/ month), the commission of agent (RM 300-600/ month), exploitation, and null period of employment. He can also lose more by not getting payment, having no freedom, no social security, experiencing sleepless nights, escaping during working hours from a police raid, and risk of deportation after being arrested. Chart 2 shows the gain and loss of an illegal worker; this is the freedom paradox of being an undocumented worker. For gaining economic freedom, they are losing true freedom. With this paradox of freedom, the Bangladeshi workers lead a low QoL even after earning higher wages then their counterpart of Bangladesh (R-11).

\section{Paradox of Housing}

With the higher wages Bangladeshi construction workers generally live in a shabby temporary house in Malaysia, because of the very nature of the job in a project (R-4). Usually, it is observed in Malaysia that, before constructing a house, a land is prepared, and a very temporary house is made with plywood or old shipping container for the workers to stay. Toilets are also of very low quality, unclean and mostly not a flashed one. The number of users is much more than prescribed in the labor law (R5). Undocumented workers, many a time even can't sleep in that house peacefully (R-6).

On the contrary, whenever a worker can save some money from the remittance, constructing a building back home is the first priority. Four main reasons came out from the field study for the

${ }^{1}$ It is an approximate data, because outsourcing company never agrees to disclose the contract they signed with the main contractor and amount of money received out of a worker. On the other hand, they never explain to the workers, how much they are deducting from each worker. 
concern of building a house in Bangladesh. Firstly, it is a symbol of having money, pride, and honor (R-4). Secondly, a beautiful house is a visible wealth, which talks about the family culture, environment, and status, on the contrary, lot of land or other forms of wealth are not visible (R-11). Thirdly, a well-built house provides security for the generations together (R-14). Finally, constructing a house means a permanent residence, a permanent address to live for the rest of the life (R-17).

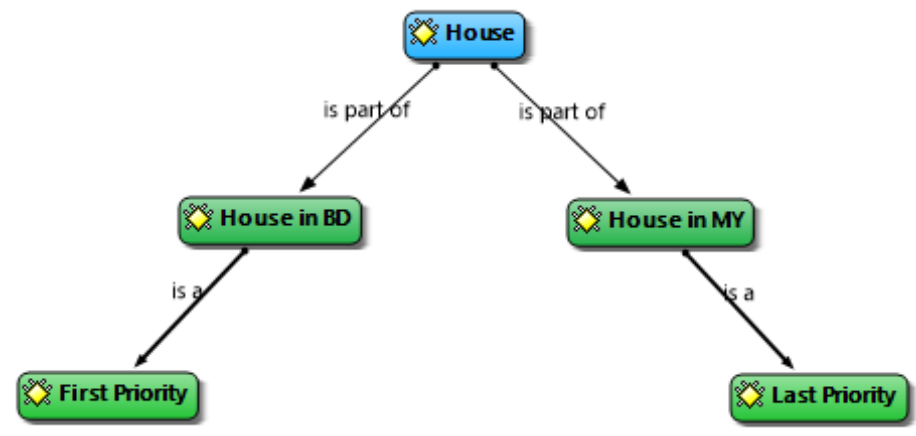

Chart 3: Paradox of Housing

Source: Output of atlas. ti from primary data collected
The paradox of housing for the construction worker is, they are preparing a beautiful house and live in a very low-quality house in one hand. On the other hand, whenever they can send some money as remittance, they construct their own house in Bangladesh. Chart 3 shows the paradox of housing in regards to Bangladesh and Malaysia. Completely opposing psychology is observed in this research, housing in Malaysia is the lowest priority to spend the night under a shed, whatever is the standard. The same person has different psychology for housing in Bangladesh,

which is the first priority. The irony of fate is the difference of house they live in Malaysia and the house they make in Bangladesh for the next generation. This is an example of self-sacrifice for the family back home (R-11).

\section{Discussion}

Researchers agree that years of migration (YoM) are important because of its time-specific effects of migration (Nowok et al., 2013) on the QoL. Migrant workers also undergo economic hardship, and initially many works even without salary (Nielsen, I., \& Sendjaya, 2014). The field study of this qualitative survay found that despite following the lowest wage (Hwa et al., 2019) many of the Bangladeshi construction workers can't manage job for the whole month and endup earning only RM 600. There are also occasions of spending half a month as jobless in search of a better job. While switching to a new job they have to leave behind the salary of last two/ three months. It is also found that if the income falls below RM 1,500 then it becomes unbearable. Income paradox found in the field survey is, opportunity of high income exist with high fluctuation, which often leads to negative balance in the initial years of migration (YoM). In the middle part of YoM, high income and high expenditure with a near to zero balance and at the end, construction workers go back with a positive balance through wealth creation.

Bangladeshi construction workers in Malaysia usually live in poor condition, which are crowded and substandard, and sleep insufficiently (Alswaidi et al., 2013). Their remittances mostly used for living expenses of their family and to finance projects such as renovating or building a house back home (Reza et al., 2019). In the same tone, field survey finds out that the project-based temporary nature of the job is superimposed over the temporary migrant status, force them to live in unsatisfactory accommodation. This non-economic aspect of housing doesn't impact at all to the undocumented 


\section{INTERNATIONAL JOURNAL OF ACADEMIC RESEARCH IN BUSINESS AND SOCIAL SCIENCES}

Vol. 10, No. 4, April, 2020, E-ISSN: 2222-6990 @ 2020 HRMARS

workers because of lack of real freedom and occasionally, sleeping outside the accommodation in the face of police raid. Housing back home (which is an economical issue of spending remittance), on the other hand is proven to be the most important issue because of the perceptions of pride, visible wealth, permanent address and security for next generations.

Lack of social security and freedom negatively impacts the social QoL among the Indonesian workers in Malaysia (Nielsen \& Sendjaya, 2014; Smyth et al., 2011). Opposing these Indonesian researchers, Bangladeshi workers perceive a lesser amount of effect of freedom on QoL. This happens because workers' sense of real freedom gets bleak out of the psychological inclination towards getting economic freedom and freedom from the unscrupulous outsourcing agents. These workers are gaining economic freedom against the face of real freedom, which seems to be a freedom trap or freedom paradox. 'Economic development through expanding the capability towards freedom of an individual to fulfill the potential of life' (Binder, 2014), is a paradox here. Figure 2: showing that freedom paradox leads to economic development, but because of violating the labor law of Malaysia, they are again leading a less meaningful life, a low QoL.

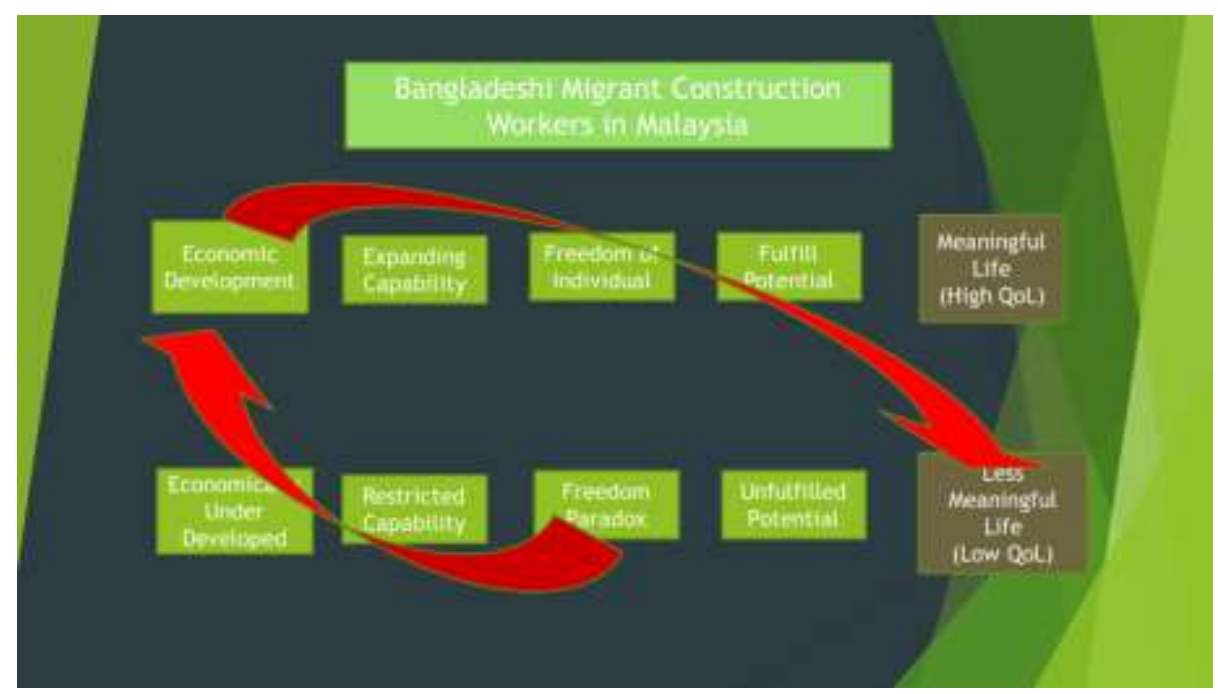

Figure 2: Relation of freedom paradox, economic development and QoL

Source: Model developed by the researcher

Malaysian law enforcement agencies and the Bangladeshi embassy.
Though, field study pointed out the dark side of being undocumented, such as being exploited and losing money, gain and loss analysis (Chart 2) showed us why many are encouraged to remain as undocumented. The workers don't understand the importance of remaining as documented and respecting the law of the land. By remaining documented, many of the exploitations could be solved with the help of

\section{Conclusion}

Bangladeshi construction workers are placing a high priority on income for economic freedom and stepping in economic trap rather than non-economic matters. Many of them are intentionally undermining the importance of legal aspects and documentation. This situation is very dangerous for a migrant worker because one can't improve the QoL by violating the law of the land. A lawbreaker always walks in the dark path of life and is afraid of the daylight, afraid to be enlightened, and thereby lacks real economic development. Many of them even spend sleepless nights away from accommodation from the fear of being arrested. House and address are rather a threat to their 
INTERNATIONAL JOURNAL OF ACADEMIC RESEARCH IN BUSINESS AND SOCIAL SCIENCES

Vol. 10, No. 4, April, 2020, E-ISSN: 2222-6990 @ 2020 HRMARS

security. That is why they put minimum importance on housing here in Malaysia and give maximum priority to housing in Bangladesh. These non-economic issues of freedom and housing pulling down the QoL of Bangladeshi migrant workers in Malaysia. Further research should be done to formulate a strategy to bring them out from this economic and non-economic paradox of QoL.

\section{References}

Alswaidi, F. M., Memish, Z. A., Al Hakeem, R. F., \& Atlam, S. A. (2013). Saudi Arabian expatriate worker fitness-screening programme: A review of 14 years of data. East Mediterr Health Journal, 19(7), 664-670.

Amit. (2010). Determinants of life satisfaction among immigrants from Western countries and from the FSU in Israel. Social Indicators Research, 96(3), 515-534.

Amit, K. (2012). Social integration and identity of immigrants from the FSU, Western countries and Ethiopia in Israel. Ethnic and Racial Studies. Social Indicators Research, 35(7), 1287-1310.

Amit, Karin, \& Riss, I. (2014). The Subjective Wellbeing of Immigrants : Pre- and Post-migration. Social Indicators Research, 247-264. https://doi.org/10.1007/s11205-013-0492

Binder, M. (2014). Subjective Wellbeing Capabilities: Bridging the Gap Between the Capability Approach and Subjective. Springer Science, 1197-1217. https://doi.org/10.1007/s10902-0139471-6

Czaika, M., \& De Haas, H. (2012). The role of internal and international relative deprivation in global migration.

D'Ambrosio, C., \& Frick, J. R. (2004). Subjective wellbeing and relative deprivation: An empirical link.

Havasi, V. (2013). Financial Situation and Its Consequences on the Quality of Life in the EU Countries. Social Indicators Research, 117, 17-35. https://doi.org/10.1007/s11205-011-9901-y

Hwa, E. P., Yap, S., Lok, P., Hamid, S. R., Cheong, C. B., \& Author, C. (2019). The Implications of National Minimum Wage Policy on the Electrical and Electronics Industry in. Global Business and Management Research, 11(2), 220-229.

Layard, R. (2010). Measuring subjective wellbeing. Science, 327(5965), 534-535. https://doi.org/10.1126/science.1186315

Khairuldin, W. M. K. F. B. W., Embong, A. H., Hassan, S. A., Yasin, M. F. M., \& Anas, W. N. I. W. N. (2019). Strategic management in fatwa-making process. Academy of Strategic Management Journal, 18(4), 1-6.

Khairuldin, W. M. K. F. W., Anas, W. N. W. I. N., Embong, A. H., Hassan, S. A., Hanapi, M. S., \& Ismail, D. (2019). Ethics of mufti in the declaration of fatwa according to islam. Journal of Legal, Ethical and Regulatory Issues, 22(5), 1-6.

Yasin, M. F. B. M., Embong, A. H., Khairuldin, W. M. K. F. W., Rahim, A., Abdullah, Sulaiman, R., Mutalib, N. A. (2018). Contributions of technology towards development of Qur'anic tajweed knowledge. International Journal of Civil Engineering and Technology, 9(6), 1340-1352.

Neto, F., Wilks, D. C., Cristina, A., \& Fonseca, M. (2019). Job - Related Well - Being of Immigrants. Social Indicators Research, 141(1), 463-475. https://doi.org/10.1007/s11205-018-1849-8

Nielsen, I., \& Sendjaya, S. (2014). Wellbeing among Indonesian labour migrants to Malaysia: Implications of the 2011 memorandum of understanding. Social Indicators Research, 117(3), 919-938.

Ghani, N. A., Yasin, S. M., Ahmed, W. S. W. A. (2010). Island Communities: Level of Quality of Life, 
INTERNATIONAL JOURNAL OF ACADEMIC RESEARCH IN BUSINESS AND SOCIAL SCIENCES

Vol. 10, No. 4, April, 2020, E-ISSN: 2222-6990 @ 2020 HRMARS

Settlements and Housing in Pulau Perhentian, Terengganu, Malaysia. Midway Journal, 5(5), 433.

Nowok, B., Van Ham, M., Findlay, A. M., \& Gayle, V. (2013). Does migration make you happy? A longitudinal study of internal migration and subjective wellbeing. Environment and Planning $A$, 45(4), 986-1002.

Preston, K., \& Grimes, A. (2019). Migration, Gender, Wages and Wellbeing : Who Gains and in Which Ways? Social Indicators Research, 144(3), 1415-1452. https://doi.org/10.1007/s11205-01902079-y

Reza, M., Subramaniam, T., \& Islam, M. R. (2019). Economic and Social Well - Being of Asian Labour Migrants: A Literature Review. Social Indicators Research, 141(3), 1245-1264. https://doi.org/10.1007/s11205-018-1876-5

Ruhs, M. (2016). Protecting the rights of temporary migrant workers: Ideals versus reality. Temporary labour migration in the global era: The regulatory challenges (J. H. \& R. Owens (ed.)). Bloomsbury Publishing.

Vicki, L., Clark, P., Creswell, J. W. (2015). Understanding Research A Consumer's Guide (J. W. Johnston (ed.); 2nd ed.). Pearson Education, Inc. file:///C:/Users/ac-asus/Desktop/PhD research/E-book for Ph.D. study/20. Creswell 2015.pdf

Yin, R. K. (2015). Qualitative Research from Start to Finish, Second Edition. Guilford Publications. 